\title{
Research on the Models of Multi-bodies Supply of Agricultural Information Service
}

\author{
WuQiong \\ Wuhan Donghu University, Wuhan, Hubei, China \\ wuqiong@163.com
}

Keywords: Multi-bodies supply; Agricultural information service

\begin{abstract}
Strengthening the construction of agricultural information service is one of the most important measures of agricultural modernization of our country and socialism new rural construction. This paper analyzes the main advantages and disadvantages of the government body, market body and public body in providing agricultural information service. We should integrate the advantages of three and construct multiple agricultural information supply models in order to improve the efficiency of agricultural information supply and promote the agricultural development in China.
\end{abstract}

\section{Introduction}

In the 21century, the information technology has become an important resource of modern science and technology competition. Agriculture information service also began to rise in the first decade of the 21 century. The use of information technology in the field of agriculture has gradually become the important way to improve agricultural competitiveness. It is through the strengthening of rural radio and network, telecom network and computer network information infrastructure construction, the full development and utilization of information resources, the construction of information service system to promote the exchange of information and knowledge sharing, and the process of realization degree of popularization and application in various rural production and management, public service, government management and the modern life consumption etc. information technology. The realization of agricultural information service to promote the modernization of agriculture and farmers' income growth is of great significance for the realization of agricultural economic development by leaps and bounds. The service of agricultural information complete and effective, will guarantee the agricultural industry structural adjustment effectively; will promote from high consumption, low efficiency of traditional agriculture to modern agriculture of high efficiency and low energy consumption; will promote reduce and the developed countries in the level of agricultural technology and agricultural productivity gap, provides the powerful safeguard for the agricultural competition the global market. Agricultural information service effectively to enliven the market and increase the income of the farmers will play an important role in promoting. At present, some local rural problems, sometimes is not absolute surplus of agricultural products, but the information services in a timely manner leading to miss the best timing of sales. The agriculture information service market information will be able to guarantee the smooth purchase and sale of agricultural products, promote the increase of farmers' income. In addition, the agricultural information service can provide for local farmers new agricultural technology, new agricultural production and organization mode and other aspects of the quality of agricultural information, improve the yield and quality of crops, a strong impetus to the farmers' income from. Therefore, in-depth study of the real information needs, and the models to supply has become essential to the construction of agriculture information service work.

\section{Multi-bodies Supply of Agricultural Information Service}

The main supply of agricultural information service can be divided intothree categories. They are the government body, the market body and the public body. The government consists of the central government,local government, management of agricultural information institutions and 
other related departments; themarket body refersto the enterprises which view the agriculturalinformation as commodity; Public body include agricultural intermediary organization, the social welfare organizations and individuals.

Government Body. Government body refers to the supplier of agricultural information service is central government,local government or other related departments. The construction of agricultural information is an important measure to solve the problems of agriculture, rural areas and farmers, is a project to benefit the people in the new rural construction, and is the fundamental guarantee for the sustainable development of agriculture. Therefore, governments at all levels should play a leading role in promoting the agricultural information construction: on the one hand, the government staff to raise awareness, to fully understand the importance of agricultural information construction of agriculture modernization, must formulate preferential policies, to create a good environment for the construction of agricultural information from various aspects, to ensure the support and guarantee of the construction of agricultural information in the capital, technology, personnel and other aspects, to strengthen the construction of hardware facilities, increase investment, construction of network infrastructure, to build a good platform; on the other hand, the construction of agricultural information service is not only the government's leader, and participants, should actively participate in the construction of agricultural information to, to take practical action to actively carry out the construction of agricultural information planning the implementation of publicity, and guide the work. Information asymmetric leads to the low efficiency of resource operation and the waste of resources, making it difficult to meet the diverse needs of the community.

Market Body. Although agricultural information is not the private goods, it cannot be supplied effectively by market like the private goods. The market can improve the efficiency of the supply of agricultural information services on the basis of construction and maintenance of the legal made by government. The existence of "government failure"offers the opportunity of the main supply of quasi-public goods outside the government to enter the field. Agricultural information for-profit companies, has enough power to provide goods of agricultural information, agricultural information enterprises will search for information, processing and sales information according to the demand of the market. Agricultural information service and government supply than the market supply the biggest advantage is that it can significantly improve the efficiency, improve the quality of quasi-public goods supply, solve the single supply of government, to meet the market demand, to provide information to produce economic effect. Although not achieve Pareto optimal, but at least it is a Pareto improvement. However, the agricultural information enterprises are faced tremendous pressure of market competition and tend to be limited to the scale of production, which is not conducive to rational resource allocation. It will lead to the slow speed of construction of agricultural information service system.

Public Body.Public body mainly refers to the non-profit organizations which supply the agricultural information to the farmers and agricultural enterprises for non- profit purposes. "Government failure" and "market failure" create the real needs in the voluntary welfare voluntary affairs mechanism. Non-profit organization is normal, people ask, non-profit characteristics, autonomy, voluntary, public welfare, the characteristics of non-profit organizations to make it in the process of the supply of quasi-public goods to the combination of efficiency and equity, with greater flexibility, has advantages of strong efficiency. But in the agricultural information service supply almost no public entities, even if there is official nature, folk spontaneous organizations rarely. There are also other problems of the public body, such as a shortage of funds, lack of volunteers and the problem of information transmission.

\section{Models of Multi-bodies Supply of Agricultural Information Service}

Agricultural information service is the essence of the problem of resource allocation. In the agricultural information service, the main body, the government public service supply subject and market subject have their respective advantages and also their shortcomings, the need to strengthen the division of labor and cooperation. From the perspective of agricultural information supply 
failure, government failure, market failure and public failure three. If the three joint supplies can contribute to the formation of mixed supply mode three, or both, can effectively avoid the defects of the three kinds of failure, give full play to the government, the public body and the main subject of market advantage. Mixed supply model of multi agent in the local government departments, public organizations and for-profit organizations depend on each other mutually cooperate and complement each other, give full play to their respective advantages to achieve the common goal of supply, improve the efficiency of the supply of agricultural information service in the whole society.

Due to the strong power of government, the public body in the current agricultural information service can only play a supporting role in the supply of agricultural information. Agricultural information service in the attributes of public goods and services in two aspects of the development trend of the product under consideration, in the current agricultural information service of our country in the implementation of the multi-agent supply mode of government guidance and market support, public participation "is feasible, but also necessary. In the agricultural information service, early, due to higher construction costs, the government occupies the dominant position completely, the agricultural information infrastructure construction and preparation work; post agricultural information enterprises to participate in, to assist the government to form and provide agricultural information services, to make up for the government to provide services for the efficiency of the supply of effective transition; government and market is the main realization of the public interest. The government provides public goods of agricultural information service in the form of the cost, often through taxation is within the government, and does not require users to pay directly; the farmers according to their own needs to pay the price for the main body of the market supply of agricultural information service. There is no economic capacity to pay, the farmers get agricultural information service may only be part of the government; economic capacity to pay is weak, agricultural information service are mostly rely on the government to provide public information products and strong market supply of cheap agricultural information. It has enough economic ability to pay and will be able to access to personal wish of agricultural information service from the agricultural information service market.

As a kind of quasi-public goods, agricultural information indicates that the government plays the role of "strong government" image in the supply process. The combination of market and government are the following four: Based on the classical liberal economic thought as the basis of the "strong weak market; government" to Keynes's "strong government based on a strong market"; in the traditional planned economy as the foundation of the thought of "strong government weak market"; "weak government Latin America in the transitional period of a weak market". With this analysis, the author thinks that in the underdeveloped areas, the government and the market should be combined with the pattern of "strong government weak market, because the micro economic entities in the region do not have a strong capacity to pay; and in the more developed the ability to pay of the economic area, the combination of market and government should be" strong government strong market". Mixed supply within some interval. Agricultural information infrastructure as the most external was the most suitable for the government bodies to complete. In the long run, with the improvement of rural infrastructure and improve the quality of the farmers, it will be transferred to the agricultural information service to public welfare organization and market forces. From the public perspective, the mixed model is a good choice to save the transaction cost.

\section{Conclusion}

The rapid development of agricultural information technologywill undoubtedly bring more benefit to the development of agriculture in twenty-first century. To strengthen the construction of agricultural information service is to accelerate the implementation of agricultural modernization of our country. The agricultural information suppliesinclude the government body, market body and public body, which all have their separate advantages and disadvantages. The government body, the public body and the market body should be based on the different comparative advantages of agricultural information service supply outside of the respective specialization mode can make the 
body get specialized economy. We should give full play to the government body, market body and society body to construct the multi-bodies supply of agricultural information to promote the development of agriculture in China.

\section{References}

[1] W. Wang, H.Y. Song. Study on Boundaries and Modelof Multi-bodies Supply ofAgricultural Information Service, J.Journal of Hubei University of Economics. 3(2013) 66 - 70.

[2] H.Y. Song, W. Wang. Research on Main Body of Agriculture Information Service and its Operation Mode, J.Pioneering with Science \& Technology Monthly.5(2013)29 - 31

[3] H.F. Mao.Research of Agricultural Information Service System in Grassroots, D. Central South University of Forestry \& Technology. 2013

[4] X.M. Zhang. Research on Current Situation and Prospect of Agricultural Information Service in China, J. Journal of Hebei Agricultural Sciences.14(2010)106 - 108 